\title{
Effects of Demographic Variables on Marital Satisfaction
}

\author{
Zainah, A. Z. ${ }^{1}$, Nasir, R. ${ }^{1}$, Ruzy Suliza Hashim² \& Noraini Md Yusof ${ }^{2}$ \\ ${ }^{1}$ School of Psychology and Human Development, Faculty of Social Sciences and Humanities, Universiti \\ Kebangsaan Malaysia, Bangi, Malaysia \\ ${ }^{2}$ School of Language Studies, Faculty of Social Sciences and Humanities, Universiti Kebangsaan Malaysia, \\ Bangi, Malaysia \\ Correspondence: Zainah, A. Z., School of Psychology and Human Development, Faculty of Social Sciences and \\ Humanities, Universiti Kebangsaan Malaysia, 43600 UKM Bangi, Selangor, Malaysia. Tel: 60-3-8921-3657. \\ E-mail: zainah@ukm.my
}

Received: June 4, 2012

doi:10.5539/ass.v8n9p46
Accepted: June 16, $2012 \quad$ Published: July 16, 2012

URL: http://dx.doi.org/10.5539/ass.v8n9p46

\begin{abstract}
Marital satisfaction is an important aspect to study because it is a global evaluation of the state of one's marriage and a reflection of marital happiness and functioning. This study aimed to ascertain the differences in marital satisfaction based on demographic variables. Subjects for this study were 423 married couples. The instrument used was ENRICH Marital Satisfaction Scale to measure marital satisfaction. The data were analyzed by inferential statistics using t-test and One-way Analysis of Variance. Results indicated significant differences in marital satisfaction based on the length of marriage and income. This study suggests that marriage counseling, with an emphasis on promoting awareness in marital happiness and satisfaction, would be helpful in addressing marital problems in married couples.
\end{abstract}

Keywords: marital satisfaction, marital happiness, marriage counseling, married couples

\section{Introduction}

Marital satisfaction has continued to be a widely investigated topic in the research on marriage and family therapy (Adams, 1988; McKenry and Price, 1988; Nye, 1988, Spanier and Lewis, 1980). Despite abundant research in this area, many scholars have pointed out some issues that need elaboration and discussion. In discussing about marital satisfaction, one would include the aspect of marital quality. According to Spanier and Lewis (1980) in the discussion of marital quality during 1960s, focus of research was on demographic, personality and social variables and how they are related to marital happiness. As for in 1970s, the emphasis was then concerned on marital adjustment and satisfaction. Later, in the 1980s, marital stability, an aspect that was seen as highly associated with marital happiness was seen as the focus of attention in marriage research (Carlson and Stinson, 1982).

According to Schoen et al. (2002), marital satisfaction is a global evaluation of the state of one's marriage and a reflection of marital happiness and functioning. From an evolutionary perspective, marital satisfaction can be viewed as a psychological state of regulated mechanisms that monitor the benefits and costs of marriage to a particular person (Shackelford and Buse, 2000).

Marital satisfaction can be evaluated from the perspectives of both husbands and wives point of view. Several factors are said to influence wives' marital satisfaction. These factors include level of intimacy, the ability to self disclose with their spouses and perceiving their partners as responsive (Laurenceau et al., 2005). Other factors include husbands' expression of affection and amount of time spent together, as well as communication styles. On the other hand, factors associated with marital satisfaction from the husbands' point of view include satisfaction with sexual relationship, division of household tasks or view of gender roles and the extent of input they perceive they get in the relationship.

Several studies (Hicks and Platt, 1970; Otto, 1979) conclude that marital happiness varies according to the stage of the family life cycle, which include factors such as number of children and their ages, occupational status of husband and wife are considered important. Other studies (Orden and Bradburn, 1968; Carlson and Stinson, 
1982) indicate that age has an increasing positive effect on marital happiness, that is the higher the age of marriage, the better the outcome in terms of marital happiness.

Factors that influence or contribute to marital satisfaction may differ across cultures. Husband's income was a more important variable for marital satisfaction in Japan as compared to United States. In another instance, marital satisfaction, life satisfaction, and self-esteem were determined by parents' and children views' of family functioning as reported by Shek (1998).

Other demographic variables explored with marital satisfaction are number of children or absence of children, level of education and length of marriage. A study by White and Edward (1990) found that the absence of children has a significant positive effect on marital happiness. In looking at the level of education, several studies (Cherlin, 1977, 1979; Janssen et al., 1998; Kalmijn, 1999) found highly educated women experience unstable marriages which lead to marital unhappiness.

It has been suggested that demographic characteristics as well as socioeconomic factors, such as education and income, could also affect marital satisfaction (Pimentel, 2000; Trudel, 2002). Research by Guo and Huang (2005) found demographic variables such as age, gender, educational attainment, number of children, presence of male children, and health conditions are significant contributors to marital satisfaction. The aim of this research is to examine the effects of demographic variables on marital satisfaction.

\section{Method}

\subsection{Participants}

The total samples consisted of 423 respondents from Malaysia. Samples were collected from various states in the country through convenient sampling. Of the 423 respondents, there were $284(67.1 \%)$ women and 139 (32.9\%) men. Majority of the respondents fall in the age group between 21-30 years $(\mathrm{n}=133,31.4 \%), 31-40$ years $(\mathrm{n}=$ 160 or $37.8 \%$ ), and $41-50$ years ( $\mathrm{n}=102$ or $24.1 \%)$. In terms of length of marriage, 226 respondents $(53.4 \%)$ were married less than 10 years and 97 (46.6\%) respondents were married 10 years of above. The respondents' income was categorized as low (below RM1500), middle (RM1501 to RM3500) and high (RM3501 and above). For this group, respondents' income for low income group ( $\mathrm{n}=174$ or $41.1 \%)$, middle $(\mathrm{n}=201$ or $47.5 \%)$ and high $(\mathrm{n}=48$ or $11.3 \%)$. As for partners' income, low group comprised of 153 (36.2\%), middle income 207 (48.9\%) and high income $48(11.3 \%)$.

\subsection{Instruments}

Marital satisfaction was measured by ENRICH which was translated to Malay language. ENRICH Marital Satisfaction Scale by Fowers and Olson (1993) or the EMS Scale is a 15-item scale comprising the Idealistic Distortion (5 items) and Marital Satisfaction Scale (10 items). Each of the 10 marital satisfaction items represents one of the areas of the marital relationship which includes personality issues, communication, conflict resolution, financial management, leisure activities, sexual relationship, children and parenting, family and friends, equalitarian roles and religious orientation. It is on a 5 point Likert scale. The highest score for the EMS is 45 and the lowest is 15 . The higher the score, the more satisfied a person is with his/her marriage.

A set of questionnaire was used to get information on the demographic information of the participants. Information on demographic variables were gathered in the demographic questionnaire section. The variables studied were age, gender, religion, ethnicity, income, length of marriage and number of children.

\subsection{Data Analysis}

Data for this study were analyzed by descriptive statistics for the demographic characteristics. T-test and one way ANOVA analyses were used to examine the differences and effects of the variables of marriage, income and partner's income.

\section{Results and Discussion}

Table 1 shows difference in marital satisfaction based on length of marriage. Results indicated that there was a significant difference in marital satisfaction based on the length of marriage $(t=3.405, p<0.05)$. Respondents with ten years and above (mean=56.14) in length of marriage were more satisfied in marriage than those with less than 10 years (mean=52.24). Table 2 shows the difference in marital satisfaction based on income. Results indicated that there was a significant difference in marital satisfaction based on income, $(\mathrm{F}=5.848, \mathrm{p}<0.05)$. Table 3 shows the difference in marital satisfaction based on partner's income. Results indicated that there was a significant difference in marital satisfaction based on spouse's income. $(\mathrm{F}=3.947, \mathrm{p}<0.05)$. (refer to Table 1 , Table 2 and Table 3). 
Table 1. T-test for difference in marital satisfaction based on length of marriage

\begin{tabular}{|c|c|c|c|c|c|}
\hline Length of marriage & $\mathrm{n}$ & Mean & SD & $\mathrm{df}$ & $\mathrm{t}$ \\
\hline Less than 10 years & 226 & 52.24 & 11.23 & \multirow[b]{2}{*}{421} & \multirow[b]{2}{*}{$3.405 *$} \\
\hline 10 years and above & 197 & 56.14 & 12.31 & & \\
\hline
\end{tabular}

$* \mathrm{p}<0.05$

Table 2. One-way ANOVA in marital satisfaction based on income

\begin{tabular}{lllll}
\hline Income & Sum of squares & df & Mean of squares & $\mathrm{F}$ \\
\hline Between groups & 1616.694 & 2 & 808.347 & \\
& & & & $5.848^{*}$ \\
Within groups & 58053055 & 420 & 138.222 & \\
\hline
\end{tabular}

$* \mathrm{p}<0.05$

Table 3. One-way ANOVA in marital satisfaction based on spouse's income

\begin{tabular}{lllll}
\hline Income & Sum of squares & df & Mean of squares & $\mathrm{F}$ \\
\hline Between groups & 1100.833 & 2 & 550.416 & \\
& & & & $3.947^{*}$ \\
Within groups & 58568.917 & 420 & 139.450 & \\
\hline
\end{tabular}

${ }^{*} \mathrm{p}<0.05$

A study by Guo and Huang (2005) found that gender, educational attainment, number of children and health condition were significant contributors to marital satisfaction. Their findings indicated that the average level of marital satisfaction for male respondents $($ male $=4.50)$ was significantly higher $(t=4.21, p<0.001)$ than that of female respondents (mean $=4.30$ ) while education, number of children and health were also positively correlated with marital satisfaction. There was also a significant gender difference in marital satisfaction.

The present study found that the longer the duration of marriage, the more satisfied the individual was with his or her marriage. A person who is satisfied with his or her marriage is an indication that he or she is also in a good relationship with his or her spouse and a good relationship is an indication of a supportive relationship (Rohany and Sakdiah, 2010). Married couples with ten years and above in their length of marriage may have passed the stage of adjustment and adaptation and will experience less psychological problems and distress. Hence, self-esteem and self-respect would be boosted and will then contribute to marital satisfaction. In addition, as suggested by Olson et al. (1983) in the Circumplex Model, high cohesion in marriage may help couples traverse difficult periods of adjustment, and balanced flexibility may keep them happy and satisfied with their marriage. Also another component in family functioning is the element of adaptability, that is relationship functioning which is neither rigid nor chaotic, seems to be an important contributing factor to marital stability.

In terms of the effect of income on marital satisfaction, high income individuals were more satisfied than those of the low income. The findings support research by Pimentel (2000) and Trudel, (2002) on income as one of the demographic factors that affect marital satisfaction.

\section{Implications for Marriage Counseling}

This study has proven that there are significant difference in marital satisfaction based on length of marriage, income and spouse income. Counselors working with married couples may want to enhance their effectiveness by understanding the nature of the demands, expectations and stress experienced by married couples that could hinder in their attaining towards marital satisfaction. This is very important because a lot of the counselor's response, strategies and approaches would rely on their understanding of the clients' situation in relation to all those demands and expectations. Since spouse support is important in contributing to the marriage life and satisfaction, it is probably necessary for marriage counselors to encourage communication and support between husbands and wives (Rohany and Sakdiah, 2010). Communication is important because it affects both marital quality and dual-career lifestyle satisfaction (Perrone and Worthington, 2001).

\section{References}

Adams, B. (1988). Fifty years of family research: What does it mean? Journal of Marriage and the Family, 50(1), 5-18. Retrieved from http://www.jstor.org/stable/352423 
Carlson, E., \& Stinson, K. (1982). Motherhood, marriage timing and marital stability. Social Forces, 61(1), 258-267. http://dx.doi.org/10.1093/sf/61.1.258

Cherlin, A. (1977). The effect of children on marital dissolution. Demography, 14(2), 265-272. http://dx.doi.org/10.2307/2060785

Cherlin, A. (1979). Work life and marital dissolution. In G. Levinger \& O.C. Moles (Eds), Divorce and separation: Context, causes and consequences. New York: Basic Books.

Fower, B. J., \& Olson, D. H. (1993). ENRICH Marital Satisfaction Scale: A brief research and clinical tool. Journal of Family Psychology, 7(2), 176-185. http://dx.doi.org/10.1037/0893-3200.7.2.176

Guo, B., \& Huang, J. (2005). Marital and sexual satisfaction in Chinese families: Exploring the Moderating Effects. Journal of Sex and Marital Therapy, 31(1), 21-29. http://dx.doi.org/10.1080/00926230590475224

Hicks, M., \& Platt, M. (1970). Marital happiness and stability: A review of the research in sixties. Journal of Marriage and the Family, 32(3), 553-574.

Janssen, J., Poortman, A., De Graf, P. M., \& Kalmijn, M. (1998). The instability of marital and cohabitating relationships in Netherlands. Mens en Maatschappij, 73, 4-26.

Kalmijn, M. (1999). Father involvement in childrearing and the perceived stability of marriage. Journal of Marriage and Family, 61(2), 409-421.

Laurenceau, J. P., Barrett, L. F., \& Rovine, M. J. (2005). The interpersonal process model of intimacy in marriage: A daily-diary and multilevel modeling approach. Journal of Family Psychology, 19(2), 314-323. http://dx.doi.org/10.1037/0893-3200.19.2.314

McKenry, P., \& Price, S. (1988). Research bias in family science: Sentimental over reason. Family Science Review, 1, 141-148.

Nye, F. (1988). Fifty years of family research, 1937-1987. Journal of Marriage and Family, 50(2), 305-316.

Olson, D. H., Russel, C. S., \& Sprenkle, D. H. (1983). Circumplex model of marital and family systems IV. Theoretical Update. Family Process, 22, 69-83. http://dx.doi.org/10.1111/j.1545-5300.1983.00069.x

Orden, S., \& Bradburn, N. (1968). Dimension of marriage happiness. American Journal of Sociology, 73(6), 715-731. Retrieved from http://www.jstor.org/stable/2775777

Otto, L. (1979). Contemporary theories about the family. New York: The Free Press.

Perrone, K. M., \& Worthington, J. E. L. (2001). Factors influencing ratings of marital quality of individuals with dual-career marriages: A conceptual model. Journal of Counseling Psychology, 48(1), 3-9. http://dx.doi.org/10.1037/0022-0167.48.1.

Pimentel, E. E. (2000). Just how do I love thee? Marital relations in urban China. Journal of Marriage and the Family, 62(1), 32-47. http://dx.doi.org/10.1111/j.1741-3737.2000.00032x

Rohany, N., \& Sakdiah, M.A. (2010). Job satisfaction, job performance and marital satisfaction among dual-worker Malay couples. The International Journal of Interdisciplinary Social Science, 5(3), 299-305.

Schakelford, T. K., \& Buss, D. M. (2000). Marital satisfaction and spousal cost-infliction. Personality and Individual Differences, 28, 917-928. http://dx.doi.org/10.1016/S0191-8869(99)00150-6

Schoen, R., Astone, N. M., Rothert, K., Standish, N. J., \& Kim, Y. J. (2002). Women employment, marital happiness and divorce. Social Forces, 81(2), 643-662. http://dx.doi.org/10.1353/sof.2003.0019

Shek, D. T. (1998). Adolescent positive mental-health and psychological symptoms-longitudinal study in Chinese context. Psychologia, 41, 217-225

Spanier, G., \& Lewis, R. (1980). Marital quality: A review of the seventies. Journal of Marriage and Family, 42(4), 825-839.

Spanier, G., \& Lewis, R. (1981). Marital quality and marital stability: A reply. Journal of Marriage and Family, 43(4), 782-783. http://dx.doi.org/10.207/351334

Trudel, G. (2002). Sexual and marital life: Results of a survey. Journal of Sex and Marital Therapy, 28(3), 229-249. http://dx.doi.org/10.1080/009262302760328271

White, L., \& Edwards, J. H. (1990). Emptying the nest and parental well-being: An analysis of national panel data. American Sociological Review, 55, 235-242. 